\title{
Quality of work life: A study conducted among IT professionals in Taramani, Chennai
}

\author{
A. Savarimuthu1, ${ }^{1,}$, S. Arulandu², G. Gayathri ${ }^{3}$ \\ ${ }^{1}$ Professor, ${ }^{3}$ Research Scholar, St. Joseph's Institute of Management, St, Joseph's College, Trichy-2, Tamil Nadu, ${ }^{2}$ Research \\ Scholar, PG \& Research Department of HRM, St, Joseph's College, Trichy-2, Tamil Nadu, India
}

*Corresponding Author:

Email: savarimuthu@jim.ac.in

\begin{abstract}
The success of an organization is highly dependent on happy and satisfied workforce. Today's organizations need to be more flexible so that they get equipped to develop their workforce according to the changing industrial scenario. Hence organizations are required to adopt a strategy to improve their employee's quality of work life to satisfy both the organizational objectives and employee needs. The term quality of work life refers to the favourableness or unfavourableness towards a total job environment for people to work. This study aims to measure such favourableness or unfavourableness by analysing four significant dimensions of workplace namely work environment, compensation and rewards, opportunities for career growth and development and work life balance of IT professionals in Taramani - The IT corridor of Chennai. The population of the study consists of 7 million units (as per CEO World Magazine Survey in 2016) among which the researcher chose 30000 units from two IT parks namely Tidal park and Ascendas for the study. The researcher had adopted a representative random sampling method by which 210 units that adequately replicates the larger population were studied to analyse the quality of work life of IT professionals in Taramani, Chennai. The researcher had used structured questionnaire with five-point scale to record the responses.
\end{abstract}

Keywords: Quality of work life, Work force, IT professionals.

\section{Introduction}

Information Technology (IT) industry in India is playing a very important role in putting India on the global map. This industry has become one of the most significant growth catalysts for the Indian economy. It has today become a growth engine for the economy, contributing substantially to increase in the GDP, urban employment and exports, to achieve the vision of a powerful and resilient India. Indian firms, across all other sectors, largely depend on the IT service providers to make their business processes efficient and streamlined. National Association of Software and Services Companies (NASSCOM) expected the IT services sector in India to grow by 13-14 per cent in 2013-14 and to touch US $\$ 225$ billion by 2020. (India Brand Equity Foundation, 2013, Aug. 23)

The major strength of IT industry lies in its human resources. Human resources play a pivotal role in the success of any IT industry. Today's IT industry concentrates on its so called intellectual capital for enhancing its growth; they make the employees committed and satisfied through providing a satisfactory quality of work life. QWL in IT industry influences job satisfaction, job involvement and organizational commitment to a greater extent as compared to other industry. (Swapna, 2015).

Though the quality of work life has always been vital, its significance came into realization during late 1960 's, when various researchers expressed their viewpoints emphasizing the importance of understanding the factors influencing work life and its behavioural impact on performance of individuals. Since then organizations have been continuously striving to understand the determinants and factors influencing quality of work life.

Particularly, Information Technology professionals possess high career aspirations and have a growing consciousness of their rights. Therefore, it is important that organizations that employ them must take adequate care to establish good quality of work life for them which will further lead to internal branding for the organizations. According to Harrison (1985) QWL is the degree to which the working organization contributes to material and psychological well-being of its members. In other words, QWL is the favourableness or unfavourableness of a job environment for people; it refers to the quality of relationship between employees and the total working environment.

Quality of Work life is a multi facet concept as it includes many other factors like adequate and fair compensation, safe and healthy working conditions, immediate opportunity to use and develop human capacities, opportunity for continued growth and security, social integration in the work organization, constitutionalisation in the work organisation, work and the total life span, the social relevance of work life as proposed by Walton (1975). These factors are positively correlated with the quality of work life in BSNL (Gupta \& Sharma 2011). Also, due to its multi dimensional nature, it is a relative concept which cannot be precisely defined and measured. Zare, H., Haghgooyan, Z and Asl, Z. K. (2012)

Rose, R.C and Beh, L.S (2006) observed that the relationship between qualities of work life and career related variables are positively related. Career achievement is positively related to Quality of Work life 
Rethinam and Ismail (2008) stated QWL is a multidimensional construct, made up of a number of interrelated factors that need careful consideration to conceptualize and measure. It is associated with job satisfaction, job involvement, motivation, productivity, health, safety and well-being, job security, competence development and balance between work and non work life and also he concluded that QWL from the perspective of IT professionals is challenging both to the individuals and organisations.

Royuela, T. J and Surinach. J. (2008) observed 10 dimensions of QWL that have been presented by European Commission. They are Intrinsic job quality, Skills, life-long learning and career development, Gender equality, Health and safety at work, Flexibility and security, Inclusion and access to the labour market, Work organization and work-life balance, Social dialogue and worker involvement, Diversity and nondiscrimination and Overall work performance. However, the measurement process of the above 10 dimensions is somewhat vary from others because it is essential to have objective indicators of QWL rather than subjective indicators. Also, there are numbers of dimensions of QWL that can be found from the empirical findings that have been conducted by various scholars. Hence based on the objectivity of the study the researcher had adopted four dimensions namely work environment, compensation and rewards, opportunities for career growth and development and work life balance to study the IT professionals in Taramani.

\section{Significance of the Study}

Quality of work life in an organization is essential for the smooth running and success of its employees. It also ensures that all employees are investing their best potential and being free from stress and strain. The Quality of work life can affect things such as employee's punctuality, his or her work output, his or her available leaves, etc. Good quality of work life helps the employees to feel secure and feel like they are being thought of and cared for by the organization in which they work. Besides all these real facts that are proved, still there exists a high level of inequality and insecurity for employees working at IT industry. Today in India a large number of young workforce are engaged in the IT and allied industry. Though this IT profession seems to be glamorous in attracting young work force, the level of job dissatisfaction leading to attrition also increases. Therefore, the researcher had made an attempt in this regard and had undertaken the current study to analyze the "Quality of work life of IT Professionals at Taramani, Chennai. This research not only helps to identify the problem but also it helps to indicate the favorable aspects, which are existing in the organization.

\section{Objectives of the Study}

1. To identify the various factors that affect the quality of work life of IT professionals at Taramani, Chennai

2. To identify the socio economic status of IT professionals at Taramani, Chennai

3. To provide necessary suggestions to improve the quality of work life of IT professionals at Taramani, Chennai

\section{Hypothesis of the study}

1. There is a significant difference between designation and hours of work of the respondents.

2. There is a significant difference between experience of the respondents and income of the respondents.

3. There is a significant difference between marital status of the respondents and their work life balance.

4. There is a significant correlation between reward mechanism and promotional opportunities.

\section{Materials and Methods}

The researcher had carried out a descriptive study to identify the various factors that affects the quality of work life of IT professionals and to provide necessary suggestions for improvement. The universe of the target group is the IT professionals working in Taramani, Chennai because there exist many IT companies. The population of the study consists of IT professionals from two major IT parks namely Tidel park and Ascendas. The researcher adopted representative random sampling which provided more viability for the study. The researcher had collected the data through interview schedule method. This method had helped the researcher to understand the quality of life in depth and so the researcher was able to record the responses of the respondents more precisely without any bias.

\section{Designation and Hours of Work}

The QWL of any person will have a straight connection to one's own designation and the time spent in daily in the work place. As the designation progresses in the vertical order, the time needed to accomplish the task assigned and the time spend in work is directly related to the quality of life at home.

H1: There is a significant difference between designation and hours of work of the respondents H0: There is no significant difference between designation and hours of work of the respondents 
Table 1: Difference between designation and hours of work of the respondents

\begin{tabular}{|c|c|c|c|c|c|c|c|}
\hline S. No & Particulars & Mean & S.D & SS & Df & MS & $\begin{array}{c}\text { Statistical } \\
\text { Inference }\end{array}$ \\
\hline 1 & Between Groups & & & 2.613 & 3 & 0.871 & $\mathrm{~F}=3.543$ \\
\hline & Fresher/Trainee (n=74) & 3 & 0.468 & & & & $.016>0.05$ \\
\hline & Junior level(n=52) & 2.81 & 0.398 & & & & Significant \\
\hline & Middle level (n=52) & 2.92 & 0.555 & & & & \\
\hline & Senior level (n=32) & 2.69 & 0.592 & & & & \\
\hline 2 & Within Groups & & & 50.644 & 206 & 0.246 & \\
\hline
\end{tabular}

One-way ANOVA ' $F$ ' test was used to test the hypothesis. The calculated value $(0.016)$ is lesser than the table value $(p>0.05)$. Hence the research hypothesis is accepted and null hypothesis is rejected. Therefore, there is a significant difference between designation and hours of work of the respondents. It could be understood that the higher the job profile the higher will be the time required to complete the task.

\section{Experience and the Income}

Experience enhances quality in performance and thus indulges in QWL as a determinant factor. There is a link between the income and the work experience in given field of execution. The study aims to find the difference between the chosen variables

H1: There is a significant difference between experience of the respondents and income of the respondents

H0: There is no significant difference between experience of the respondents and income of the respondents

Table 2: Difference between experience of the respondents and their income

\begin{tabular}{|l|c|c|c|c|c|c|c|}
\hline S. No & Particulars & Mean & S.D & SS & Df & MS & Statistical Inference \\
\hline 1 & Between Groups & & & 57.03 & 3 & 19.01 & F=43.818 \\
\hline & Below-2yrs (n=102) & 1.94 & 0.504 & & & & $.000>0.05$ \\
\hline & $2-5 \mathrm{yrs}(\mathrm{n}=54)$ & 2.52 & 0.746 & & & & \multirow{2}{*}{ Highly Significant } \\
\hline & $6-8 \mathrm{yrs}(\mathrm{n}=26)$ & 2.85 & 0.675 & & & & \\
\hline & above 8yrs(n=28) & 3.43 & 0.92 & & & & \\
\hline 2 & Within Groups & & & 89.37 & 206 & 0.434 & \\
\hline
\end{tabular}

One-way ANOVA ' $F$ ' test was used to test the hypothesis. The calculated value $(0.00)$ is lesser than the table value $(p>0.05)$. Hence the research hypothesis is accepted and null hypothesis is rejected. Therefore, the difference between experience of the respondents and their income is a highly significant. The result confirms the common parlance understanding between the variables.

\section{Marital status and the QWL}

The QWL varies according to the stages of life like bachelorhood and married lie. Unmarried life is more casual than the married life where the responsibility and commitment seems to be more and demanding.

$\mathbf{H}_{1}$ : There is a significant difference between marital status of the respondents and their work life balance

$\mathbf{H}_{\mathbf{0}}$ : There is no significant difference between marital status of the respondents and their work life balance

Table 3: Difference between marital status of the respondents and their quality of work life

\begin{tabular}{|l|c|c|c|c|c|}
\hline S. No & Particulars & Mean & S.D & $\begin{array}{c}\text { Statistical } \\
\text { Inference }\end{array}$ & S. No \\
\hline 1 & $\begin{array}{c}\text { I regularly go out for } \\
\text { recreations }\end{array}$ & Single (n=157) & 3.36 & .948 & $\mathrm{~T}=-1.227 \mathrm{Df}=208$ \\
\cline { 3 - 5 } & Married(n=53) & 3.55 & .932 & $\begin{array}{c}0.221>0.05 \text { Not } \\
\text { significant }\end{array}$ \\
\hline 2 & $\begin{array}{c}\text { I spend quality time } \\
\text { for my family }\end{array}$ & Single (n=157) & 3.45 & 1.046 & $\begin{array}{c}\mathrm{T}=1.090 \mathrm{Df}=208 \\
0.277>0.05 \text { Not } \\
\text { significant }\end{array}$ \\
\cline { 3 - 5 } & Married(n=53) & 3.26 & 1.059 & .942 & $\begin{array}{c}\mathrm{T}=-0.959 \mathrm{Df}=208 \\
0.339>0.05 \mathrm{Not} \\
\text { significant }\end{array}$ \\
\hline
\end{tabular}


T-test was used to test the hypothesis. The calculated value is greater than the table value $(\mathrm{p}<0.05)$ thus the research hypothesis is rejected and null hypothesis is accepted. Therefore, there is no significant difference between marital status of the respondents and their quality of work life. The understanding from the table is that the person is either married or unmarried that makes no difference in making both ends meet in the area of life and work.

\section{Promotional Opportunities and QWL}

The pioneer to put forth the elements of QWL was Walton (19730). One of the factor propounded by him is the continuous opportunity to grow in the organisation. It is the promotional opportunities that motivate the employees to look for continuous development and growth. It is expected of the organisation to facilitate for training and developmental programmes either inside or outside of the organisation

H1: There is a significant correlation between promotional opportunities and QWL

H0: There is a significant correlation between promotional opportunities and QWL

Table 4: Correlation between promotional opportunities and QWL

\begin{tabular}{|l|c|c|c|}
\hline \multirow{2}{*}{ Particulars } & $\begin{array}{c}\text { Promotional } \\
\text { Opportunities }\end{array}$ & QWL \\
\hline \multirow{3}{*}{$\begin{array}{l}\text { Promotional } \\
\text { Opportunities }\end{array}$} & Pearson's correlation & 1 & $0.478^{* *}$ \\
\cline { 2 - 4 } & sig (2-tailed) & & 0.000 \\
\cline { 2 - 4 } & $\mathrm{N}$ & $0.478^{* *}$ & 210 \\
\cline { 2 - 4 } & Pearson's correlation & 0.000 & 1 \\
\cline { 2 - 4 } & sig (2-tailed) & 210 & 210 \\
\hline
\end{tabular}

Karl Pearson's coefficient of correlation is used to test the hypothesis. The calculated value (0.478) lies in between -1 and 1 thus the research hypothesis is accepted and null hypothesis is rejected. Therefore, there is a significant correlation between promotional opportunities and QWL.

\section{Results and Discussion}

Mostly men $(75.2 \%)$ who are single $(74.8 \%)$ work in IT industry. IT professionals are between 20 years to 30years $(83.8 \%)$ and they have completed their postgraduation $(62.9 \%)$. Freshers $(48.6 \%)$ are recruited at large. They work for 8-10 hours per day (79\%) and earn between Rs. 10000 to Rs.30000 (57. 1\%). But there exists a significant difference between designation and hours of work.

IT professionals enjoy adequate facilities $(51.4 \%)$ to deliver their work effectively. They work in a motivating environment $(56.2 \%)$ where their opinions and suggestions are considered by the top management $(41.9 \%)$ without any sort of discrimination $(38.1 \%)$. Despite this considerable number of IT professionals (37.1\%) neither agree nor disagree to the fact that their level of job stress is very less at work place also there is no significant relationship between age and job stress of the IT professionals. Since they are provided with fair and reasonable work environment.

IT professionals are paid fairly $(44.8 \%)$ based on their performance $(47.6 \%)$ without any disparity in pay among the counter parts $(46.7 \%)$. They also agree that reward mechanisms are encouraging (47.6\%) establishing a significant relationship between the appraisal system and promotional opportunities and they were able to manage their financial commitments out of their pay (41\%). Therefore, they enjoy good compensation and reward packages. But there exists a significant difference between experience and income of the IT professionals.

Since the job of the IT professional is quite challenging $(49.5 \%)$ they are imparted with adequate training $(60 \%)$ to perform the task so that they gain new knowledge through their job (47.6\%). They also enjoy good degree of freedom $(48.6 \%)$ to build their career with promotional avenues $(45.7 \%)$. The understanding is that, they are provided with opportunities for career growth and development.

Besides this IT professional are covered with good social security $(44.8 \%)$. They also maintain a cordial relationship among their colleagues $(48.6 \%)$ and spend quality time with their family $(41.9 \%)$ by going out for recreations regularly (41.9\%) thus establishing a good level of work life balance and there is no significant difference between marital status and work life balance of the IT professionals but surprisingly only limited number of IT professionals $(36.2 \%)$ prefer to work in IT industry for long time.

\section{Conclusion}

Based on the findings of the study the researcher would like to propose a few suggestions for improving the quality of work life of IT professionals. Though there exists a reasonable level of quality of work life it could be enhanced so that the IT industry will get highly committed work force. The IT industry recruits freshers at large hence they require high intensity orientation and induction about the job and industry as they are working without completely understanding their business process 
and also it would be very difficult to imbibe them with professional maturity. Therefore, they can also consider candidates with zero to two years of experience for junior level vacancies.

The employees who work as trainees or as junior level executives exits the organisation within two years hence increasing the rate of attrition. This form of attrition should be reduced because the company invests more on training such employees. These employees could be retained if the management redefine their implicit promotional policies like expectation of long term commitment from a employee if he or she have to be promoted.

The practice of making the employees work in teams is appreciable but there exists a criticism that important projects are allotted to experienced employees and their team though they do not have knowledge about that subject. Therefore, projects should be allotted based on the employee's competency and not experience. Also there exists a general belief by the junior executives that reward mechanisms favours only experienced employees therefore it is essential to address this issue and bridge the relationship between junior and senior employees.

Conclusively, regular measurement and assessment of Quality of Work Life (QWL) can potentially provide the IT industry with important information about the welfare and expectations of their employees such as job satisfaction, work-family balance, job security and job stress. Information Technology professionals are highly educated with high career aspirations and have a growing consciousness of their rights. Hence it is only imperative that organizations that employ them must be concerned about their quality of work life which further will lead to internal branding in the organizations.

\section{References}

1. CEO world Magazine. (2016, December2). India's top 12 Tech. Cities: Digital Indian Cities survey, 2016.
Retrieved from http://ceoworld.biz/2016/12/02/indiastop-12-tech-cities-digital-indian-cities-survey-2016/

2. Gupta, M \& Sharma, P (2011) Factor credentials Boosting Quality of Work Life of BSNL Employees in Jammu Region. Sri Krishna International Research and Educational Consortium, Volume 2, Issue 1, 79-89

3. Harrison T.M. Communication and Participative Decision Making: An Exploratory Study; Personnel Psychology, 1985;1:97-116.

4. India Brand Equity Foundation1: (2018, June). IT \& ITes Industry in India. Retrieved

fromhttps://www.ibef.org/industry/informationtechnology-india.aspx

5. Nayak, S. \& Joshi, H.G. (n.d.). Quality of Work life among IT professionals in SME'S in select cities of India. Journal of Law and Social Sciences. 1(1).

6. Rethinam, G. S., \& Ismail, M. Constructs of Quality of Work Life: A Perspective of Information and Technology professionals. European Journal of Social Sciences. 2008;7:58-70.

7. Rose, R C and Beh, L. S. An analysis of Quality of Work Life and Career- Related variables. American Journal of Applied Sciences. 2006;3(12):2151-2159.

8. Royuela, V., López-Tamayo, J., \& Suriñach, J. The institutional vs. the academic definition of the quality of work life. What is the focus of the European Commission? Social Indicators Research, 2008;86(3):401-415. https://doi.org/10.1007/s11205-0079175-6

9. Swapna, M. Quality of Work life Metrics as a predictor of job satisfaction and organisational commitment: A study with special reference to Information Technology Industry. Mediterranean Journal of Social Sciences. 2015;6(3):52.

10. The Media Ant. (2018) Advertising in IT park- Ascendas IT park, Tidal park, Chennai. Retrieved from https://www.themediaant.com/nontraditional/it-parkascendas-it-park-tidel-park-chennai-advertising-10422

11. Walton, R. E. Quality of Working Life: What Is It?, Sloan Management Review. 1973;15(1):11-21.

12. Zare, H., Haghgooyan, Z and Asl, Z. K. Determining and Prioritizing the Criteria and Scales of Quality of Work Life (QWL) by AHP Method. European Journal of Social Sciences. 2012;27(3):346-359. 